\title{
Infantile Langerhans Cell Histiocytosis Presenting as Otitis Media \& Lymphadenopathy - A Case Report
}

\author{
Ajitha Kumari K. ${ }^{1}$, Jijo Joseph John², Chandana Chandran³, Girija Mohan ${ }^{4}$ \\ ${ }^{1}$ Department of Pathology, Believers Church Medical College, Thiruvalla, Kerala, India. \\ 2,4 Department of Paediatrics, Believers Church Medical College, Thiruvalla, Kerala, India. \\ ${ }^{3}$ Department of Paediatric Surgery, Believers Church Medical College, Thiruvalla, Kerala, India.
}

\section{INTRODUCTION}

Langerhans-cell histiocytosis is a rare disease previously known as histiocytosis X. It occurs as a result of clonal proliferation of CD1a positive Langerhans cells in the body. LCH includes a spectrum of disorders involving multiple organs and tissues and may cause multi organ dysfunction with fatal outcome. The most common form of the disease however involves a single organ usually the bone and has an excellent prognosis with appropriate therapy. Clinical manifestations are often heterogeneous and the diagnosis of this condition can be challenging at times due to clinical and morphological overlapping with other conditions. In a patient presenting with otitis media the condition can very easily be overlooked in the absence of other systemic manifestations.

\section{PRESENTATION OF CASE}

A 2 months and 22 days old female child presented with acute suppurative otitis media and cervical lymphadenopathy. After a month of adequate therapy with appropriate antibiotics, child presented with persistent cervical lymphadenopathy. Bilateral enlarged inguinal lymph nodes were also noted. Lymph nodes were firm in consistency and the largest lymph node measured $2.5 \times 1 \mathrm{cms}$. All other clinical parameters were within normal limits. As it was unusual to have such inguinal lymphadenopathy in an infant, further investigations were done. Routine blood examination was within normal limits. Serological investigation revealed minimal rise in CMV IgG (cytomegalovirus immunoglobulin G).

Excision biopsy of a lymph node was done. The specimen was received as multiple pieces, largest measuring 2 × 1.5 x $0.8 \mathrm{cms}$. Microscopic examination showed lymphoid tissue with areas of necrosis and a diffuse cellular infiltrate composed predominantly of large polygonal cells with abundant eosinophilic cytoplasm with round, oval or elongated nuclei showing fine chromatin and distinct nuclear grooving.
Corresponding Author: Dr. Ajitha Kumari K, Department of Pathology, Believers Church Medical College, Thiruvalla, Kerala, India. E-mail: ajithakdr@gmail.com

DOI: $10.14260 / j e m d s / 2020 / 874$

How to Cite This Article:

Kumari K.A, John J.J, Chandran C, et al. Infantile langerhans cell histiocytosis presenting as otitis media \& lymphadenopathy - a case report. J Evolution Med Dent Sci 2020;9(52):40034005, DOI: 10.14260/jemds/2020/874

Submission 04-09-2020,

Peer Review 01-11-2020,

Acceptance 09-11-2020,

Published 28-12-2020.

Copyright (C) 2020 Ajitha Kumari K. et al. This is an open access article distributed under Creative Commons Attribution License [Attribution 4.0 International (CC BY 4.0)] 
Focal collections of lymphoplasmacytic cells were seen but eosinophils were scant (Figure 1). Immunohistochemistry showed S100 and CD1a positivity in the larger cells labelling the tumour as Langerhans-cell histiocytosis (Figure 2). Cytogenetic studies for BRAF \& MAP2K1 mutation analysis were not done due to non-availability of facilities. The child was referred to specialized centre for chemotherapy. Radiological skeletal survey was done before initiating therapy which revealed lytic lesions in the skull bones.
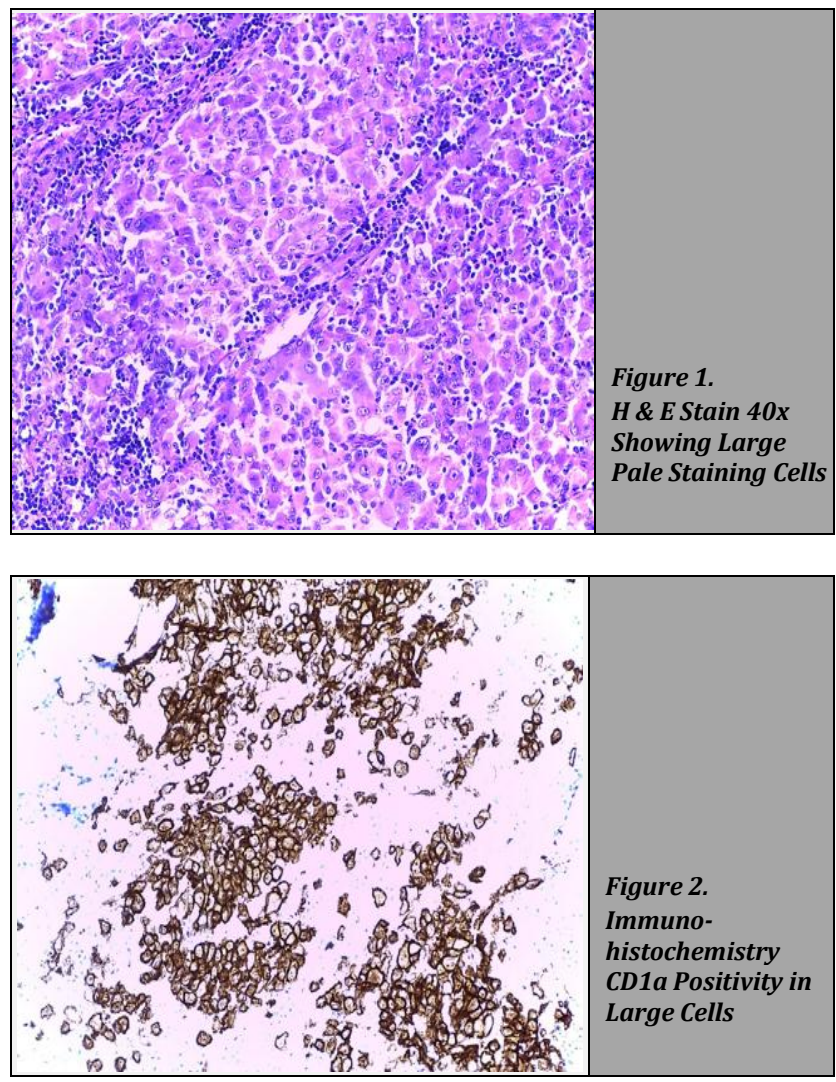

\section{DISCUSSION}

Langerhans cells are dendritic mononuclear cells which form a subset of histiocytes and act as antigen presenting cells normally. In $\mathrm{LCH}$, there is monoclonal proliferation and accumulation of immature Langerhans cells with formation of tumour masses in different tissues of the body. These cells invade different organs and tissues of the body causing tissue destruction.

LCH is a disease with a wide spectrum of organ involvement and clinical manifestations. It can present as a single system disease or as multisystem disease. The organs involved are bone, skin, lymph nodes, liver, spleen endocrine organs, lungs, central nervous systems, ears, gums and almost any other organ either alone or in combination. In more than $75 \%$ of the cases, patient presents with only bone involvement mostly the skull bones. Bone involvement in LCH can be solitary or multiple lytic lesions. In the present case report, in addition to the lymph node involvement and history of ASOM, (acute suppurative otitis media) there was radiological evidence for lytic lesions in the skull bone and hence it has to be considered as a multi organ involvement.

The initial presentation of LCH with otitis media is very rare. ${ }^{1}$ Clinical presentation of LCH with lymphadenopathy can mimic lymphoma clinically. Dominant clinical manifestation of our case was significant lymphadenopathy suggesting that LCH should also be considered in the clinical differential diagnosis in such cases and biopsy becomes mandatory to confirm the diagnosis. ${ }^{2}$

Any age group can be affected by LCH. In children it is most often seen between the ages of 1 - 4 years with a male predilection. But it is rare in new-born and very young infants. Congenital form of LCH is called Hashimoto-Pritzker disease which present with deep subcutaneous lesions and is selfhealing. In our case, the baby was less than 3 months old.

The exact aetiology of this condition is unknown. Possible aetiologic factors suggested include viral infections, toxins in the environment and genetic factors. Viruses especially CMV are thought to have a triggering effect in LCH. In our patient there was a minimal rise in CMV IgG. But the presence of the virus in tissue was not confirmed by immunohistochemical methods. Various studies which utilised polymerase chain reaction techniques and sensitive in situ hybridisation methods have failed to establish the link between LCH and viruses. 3,4

Earlier, it was considered as a reactive proliferation of histiocytes but the recent identification of specific BRAF and MAP2K1 mutations in these cells justifies the classification of LCH as a neoplastic process. ${ }^{5}$

As there are no pathognomonic clinical or radiological features, definite diagnosis of the condition is made possible by tissue biopsy and histopathological examination supported by immunohistochemistry

Baby was referred to a centre with paediatric oncologist. On evaluation there with skeletal survey, lytic lesions were detected on the temporal bone including the middle year bones. She was started on chemotherapy with a standard two drug regimen including vinblastine and prednisolone, an intensive phase for 2 months and then maintenance for 18 months. She responded well to chemotherapy. Skeletal survey after one and half years showed no lesions. Child is doing well, having normal growth and development and is under regular follow up.

\section{CONCLUSIONS}

When a child presents with otitis media and lymphadenopathy affecting more than one anatomical sites, a high index of suspicion is always required to recognize the disease entity. It is always advisable to do a biopsy with immunohistochemistry in such cases to establish the diagnosis.

Financial or other competing interests: None.

Disclosure forms provided by the authors are available with the full text of this article at jemds.com.

\section{REFERENCES}

[1] Skoulakis CE, Drivas EI, Papadakis CE, et al. Langerhans cell histiocytosis presented as bilateral otitis media and mastoiditis. Turk J Pediatr 2008;50(1):70-3.

[2] Madasu A, Rana AN, Banat S, et al. Langerhans cell histiocytosis in an infant mimicking a lymphoma at 
presentation. Case Reports in Hematology. Hindawi Publishing Corporation 2015;2015:1-4.

[3] Khoddami M, Nadji SA, Dehghanian $P$, et al. Cytomegalovirus and langerhans cell histiocytosis: is there a link? Iran J Pediatr 2016;26(2):e673.
[4] McClain K, Jin H, Gresik V, et al. Langerhans cell histiocytosis: lack of a viral etiology. Am J Hematol 1994;47(1):16-20.

[5] Alayed K, Medeiros LJ, Patel KP, et al. BRAF and MAP2K1 mutations in Langerhans cell histiocytosis: a study of 50 cases. Hum Pathol 2016;52:61-7. 